\title{
II Międzynarodowa Konferencja „Wsparcie i samoświadomość społeczna $w$ resocjalizacji inkluzyjnej. Osoba, wspólnota, kultura" (Warszawa, 22 maja 2015 r.)
}

Zorganizowana przez Katedrę Profilaktyki Społecznej i Resocjalizacji UKSW, Koło Naukowe Studentów Pedagogiki Resocjalizacyjnej UKSW oraz Katholische Hochschule Mainz międzynarodowa konferencja naukowa była drugą z cyklu „Oblicza marginalizacji społecznej”. Tak jak za pierwszym razem odbyła się ona na Wydziale Nauk Pedagogicznych (WNP) Uniwersytetu Kardynała Stefana Wyszyńskiego w Warszawie. Wzięło w niej udział wielu wybitnych znawców teorii resocjalizacji i praktyków z tego zakresu.

Licznie zebranych gości i studentów WNP oraz Studenckiego Koła Naukowego Profilaktyki i Resocjalizacji Uniwersytetu Warszawskiego przywitała opiekunka Koła Naukowego Studentów Pedagogiki Resocjalizacyjnej - dr hab. prof. UKSW Anna Fidelus, prodziekan Wydziału Nauk Pedagogicznych.

Pierwszym prelegentem był prof. zw. dr hab. Andrzej Bałandynowicz z Uniwersytetu Przyrodniczo-Humanistycznego w Siedlcach, który wygłosił wykład pt. Osobowe, wspólnotowe i kulturowe uwarunkowania procesu wielopasmowej resocjalizacji skazanych $z$ udziałem społeczeństwa. Podczas wystąpienia poruszone zostały zagadnienia $\mathrm{z}$ 40-letniej praktyki profesora $\mathrm{w}$ dziedzinie badań nad recydywistami. Omówione zostały badania losów skazanych przed popełnieniem przestępstwa i po nim, czyli w oparciu o anamnezę i katamnezę, oraz badania longitudinalne - losów skazanych na przestrzeni ich całego życia.

Następnie sekretarz stanu w Ministerstwie Sprawiedliwości, minister Jerzy Kozdroń przedstawił referat pt. Demoralizacja i przestępczość nieletnich - przyczyny oraz środki reagowania, w którym poruszył kwestię funkcjonowania młodzieży w zakładach poprawczych, a także podkreślił znaczenie diagnozy osobowości nieletniego sprawcy czynu karalnego, w której formułowaniu znaczącą rolę odgrywają pedagodzy, psychologowie oraz przedstawiciele medycyny. Minister zwrócił również uwagę na rolę biegłych w sądzeniu spraw rodzinnych, którzy wydają istotne opinie o stanie psychicznym nieletniego.

Kolejnym prelegentem była sędzia Jolanta Zagajewska - zastępca dyrektora Departamentu Wykonania Orzeczeń i Probacji Ministerstwa Sprawiedliwości, 
która zaprezentowała temat Resocjalizacja $w$ teorii i praktyce zakładów poprawczych - ze szczególnym uwzględnieniem metod oddziaływania wobec nieletnich. W swoim wystąpieniu zwróciła uwagę na to, że najczęściej stosowanym środkiem wychowawczym w 2014 roku w stosunku do nieletniego było upomnienie oraz przyznanie nadzoru kuratora. Sędzia podkreśliła również, jak ważne jest indywidualne podejmowanie decyzji w sprawie każdego nieletniego, a więc nie tylko dokładne posługiwanie się środkami zawartymi w Ustawie o postępowaniu $w$ sprawach nieletnich, lecz przede wszystkim skupienie się na każdej sferze funkcjonowania młodego człowieka, a więc życiu rodzinnym, szkolnym i szeroko rozumianych kręgach społecznych, w których zachodzi proces socjalizacji.

W dalszej części konferencji swoimi doświadczeniami z pracy ze skazanymi podzielił się pułkownik Bogdan Kornatowski - dyrektor Aresztu Śledczego Warszawa-Mokotów, a wcześniej wychowawca skazanych. Wygłosił referat pt. Funkcjonowanie aresztu śledczego - metody i środki oddziaływań wychowawczych. $\mathrm{W}$ areszcie tym aktualnie przebywa 7186 skazanych, nad którymi opiekę sprawuje 2359 funkcjonariuszy Służby Więziennej. Dyrektor podkreślił swoje zamiłowanie do pracy i zwrócił uwagę na realizowanie w mokotowskim zakładzie wielu programów, które sprzyjają readaptacji skazanych i są pomocne w walce z nałogami, dzięki czemu zapobiegają recydywie.

Kolejną prelekcję, pt. Wsparcie, zaufanie i komfort społeczny rodzin osób karanych w procesie resocjalizacji inkluzyjnej, wygłosiła dr hab. prof. UJK Anna Kieszkowska z Uniwersytetu Jana Kochanowskiego w Kielcach. Omówiła istotę procesu reintegracji osób skazanych w ich środowisku otwartym. Rodzina i społeczeństwo lokalne powinny wspierać byłego skazanego, by wzbudzać w nim zaangażowanie w samostanowienie oraz wzmacniać samoocenę, i w ten sposób podnosić jego poczucie własnej wartości.

Z kolei pułkownik Jarosław Kardaś - zastępca dyrektora generalnego Służby Więziennej - przygotował referat pt. Wyzwania modernizacyjne służby więziennej $w$ świetle strategii rozwoju państwa do 2030 roku, w którym przedstawione zostały plany nowoczesnych obiektów penitencjarnych, sprzyjających skutecznej i efektywnej resocjalizacji osadzonych w XXI wieku.

Po przerwie drugą część spotkania rozpoczęło wystąpienie Romualda Sadowskiego - dyrektora Schroniska dla Nieletnich i Zakładu Poprawczego w Warszawie-Falenicy. W swoim referacie pt. Tutoring $w$ resocjalizacji wychowanek Zakładu Poprawczego i Schroniska dla Nieletnich w Falenicy - pomoc byłym wychowankom przytoczył historie młodych kobiet, które po opuszczeniu zakładu nadal utrzymują kontakt z jego kadrą, a znaczna część z nich zakłada własną rodzinę, w której prawidłowo funkcjonuje. Podkreślił również fakt, że duży procent wychowanek to dziewczyny, których matki w przeszłości również przebywały w zakładzie poprawczym.

Następnie dr Tomasz Przesławski z Uniwersytetu Warszawskiego, który przybył wraz ze studentami Instytutu Profilaktyki Społecznej i Resocjalizacji Wydziału 
Stosowanych Nauk Społecznych i Resocjalizacji, wygłosił prelekcję pt. Konsekwencje naruszenia zasady humanitaryzmu i poszanowania godności ludzkiej w postępowaniu karno-wychowawczym. W swoim przemówieniu dostrzegł znaczenie humanitaryzmu, który jest jedną ze znaczących zasad prawa karnego. Zwrócił zatem uwagę na godność osoby ludzkiej, która wpisuje się w tę zasadę, a o której należy pamiętać w momencie orzekania kary, środków karnych czy też środków zabezpieczających wobec osoby naruszającej normy prawa.

$\mathrm{Na}$ zakończenie referat pt. Samoświadomość skazanych a proces readaptacji społecznej wygłosiła dr hab. prof. UKSW Anna Fidelus. W swoim wystąpieniu podkreśliła, że proces readaptacji społecznej skazanych uzależniony jest od wzajemnie powiązanych i oddziałujących na siebie różnorodnych czynników wewnętrznych i zewnętrznych. Prowadzone przez Annę Fidelus badania wskazują na ogromne znaczenie samoświadomości skazanych w procesie readaptacji społecznej. Pełni ona w tym procesie rolę katalizatora, pozwalającego na efektywne wykorzystanie poszczególnych determinantów readaptacji społecznej. Jak zauważyła prelegentka, samoświadomość jest „łącznikiem i regulatorem wewnętrznych odczuć i zewnętrznych okoliczności w readaptacji skazanych, jest niezbędnym spoiwem umożliwiającym harmonijną relację pomiędzy obydwiema grupami zasobów".

Konferencja była czasem wymiany ważnych naukowych poglądów, dotyczących wsparcia i samoświadomości społecznej w resocjalizacji inkluzyjnej. W jej trakcie przedstawiciele świata teorii i praktyki mogli podzielić się swoim doświadczeniem $\mathrm{z}$ zakresu pracy z różnymi grupami społecznymi działającymi w obrębie resocjalizacji, co wzbudziło także zainteresowanie studentów. 